\title{
Exploring Impact of Corporate Social Responsibility on Organizational Performance, the Case of Turkish Islamic Banks
}

\author{
Ashraf Elsafty ${ }^{1} \&$ Abdelaziz Tahon ${ }^{1}$ \\ ${ }^{1}$ Adjunct Assistant Professor, Maastricht School of Management, Cairo Outreach, Egypt \\ ${ }^{1}$ Doctoral Candidate, Senior Consultant, Istanbul, Turkey \\ Correspondence: Ashraf Elsafty, Adjunct Assistant Professor, Maastricht School of Management, Cairo Outreach, \\ Egypt. ORCID ID: https://orcid.org/0000-0002-9377-7286
}

Received: November 24, 2020

Accepted: December 18, 2020

Online Published: December 22, 2020

doi:10.11114/bms.v7i1.5087

URL: https://doi.org/10.11114/bms.v7i1.5087

\begin{abstract}
This paper attempts to explore the impact of corporate social responsibility activities on organizational performance through focusing on Turkish Islamic banks as a dynamic organization and growing at high rate over past two decades. The paper focused also on Turkish Islamic banks stakeholders' area which reflect the bank performance and CSR activities and how to monitor the impact through many tools, to explore this relationship, CSR activates used as the independent variable and organizational performance as the dependent variable within the theoretical framework and hypotheses addressed by the paper investigation. then depending on narrative approach of data collection through interviews, with different segments of stakeholders and discussions based on direct questions according to each segment type. Paper explained CSR definitions and theories, discussed its relationship with modern global trends and focused on stakeholder approach for explaining the real meaning of CSR. As this approach concerned about stakeholders needs and reflects the corporation interest from them. The paper used the stakeholders' approach in measuring social responsibility, where the impact of social responsibility was known through the direct approach towards the stakeholders. While for organizational performance focused on tools and models that measure performance, using the balanced score cards to apply it on the study through its four major sides (financial, operations, customers and research \& development). Major recommendations focused on critical need of CSR deployment, with clear function/department in chars, CRS impact reputation directly, and the high demand on Islamic banking services may decline by time, but it can be maintained through CSR activities.
\end{abstract}

Keywords: Corporate Social Responsibilities, organizational performance, stakeholders, Turkish Islamic Banking

\section{Introduction}

In the global market and through the research, it is argued that Corporate Social Responsibility (CSR) can be a source of innovation and business advantage. The development of the concept of CSR as not only a charitable deed, but a competitive advantage has been evolving since the early 1950's. Corporations are exploring and adapting strategy that is more corporately responsible. Stakeholders are encouraged to trust in a management practice and commitment to CSR, meanwhile managers as well as shareholders are understanding and responding to the increasing demand.

By time, organizations and the private sector have grown to the awareness that they should have an active role towards their society, as well as making profit and guaranteeing high returns to their shareholders. The Turkish Islamic Banks have grown aware to this strategy. They became familiar with the concept and started adapting CSR as strategy and started becoming more involved in the well-being of their society. Some of the companies started making this information public, by publishing reports announcing their CSR policies and projects. They also started advertising those projects as well as involving employees in applying those practices.

According to Elsafty (2018) the Nine Elements Framework/Model can cover all sides around our problem we can understand our research problem through this model which explore the kind of research organization, management level, business functions, internal \& External environmental factors, geographical location and industry field we can explore all of this elements within time frame. 


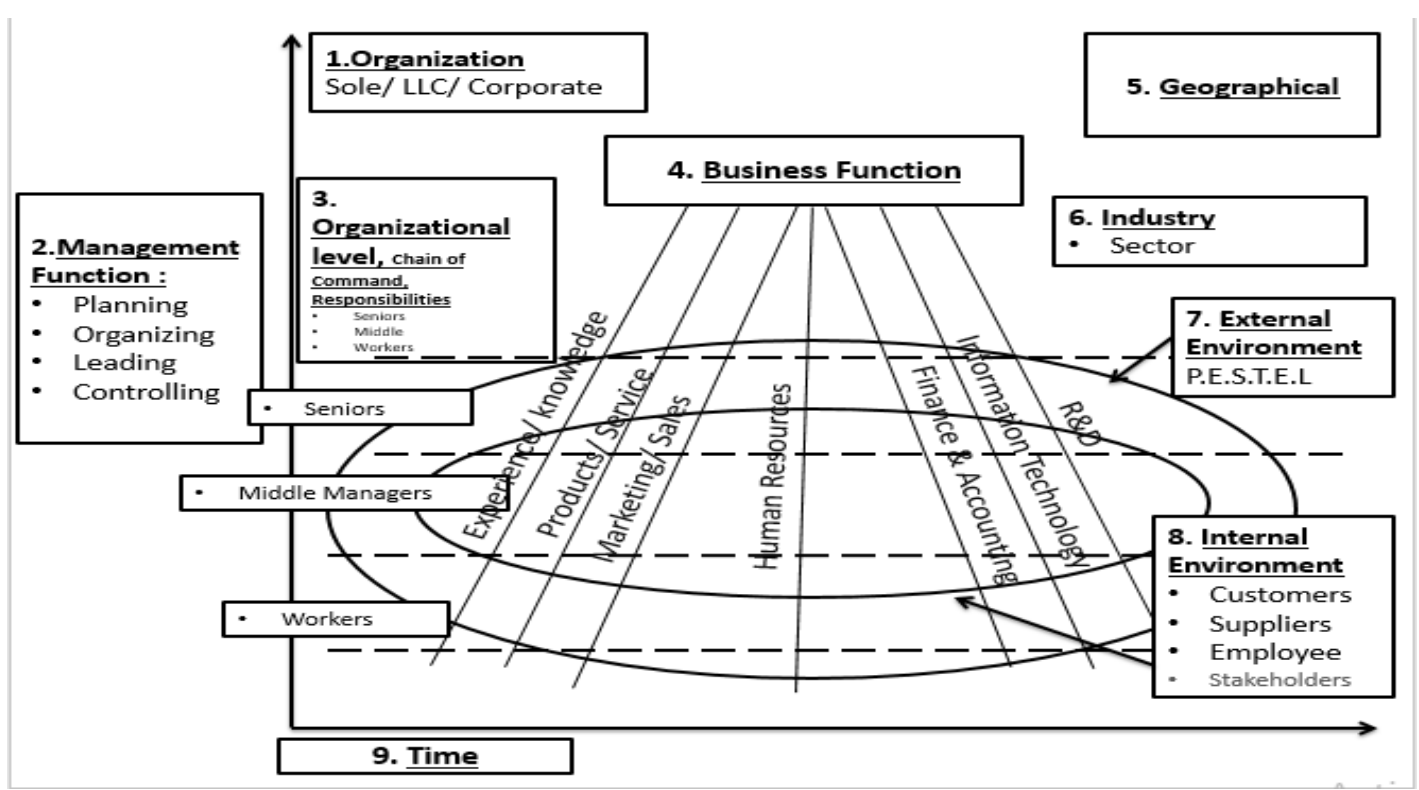

Figure 1.1 The nine elements (ElSafty, 2018)

In order to ensure a comprehensive contextual analysis, researchers analyzed the research in hand with the perspective of the proposed contextual framework of Elsafty (2018) that analyzes social study cases, as an anatomy model to closely study organizations and different contextual cases before attempting to solve any noticeable problems. On the way to contextual analysis of the research, Elsafty $(2018,2019,2020)$ provided a holistic framework to analyze the case using nine elements covering the whole ecosystem of educational organization(s) and all related stakeholders, including suppliers, distributors, customers, competitors, government agencies, and so on - involved in the delivery of educational outcomes, and related service through both competition and cooperation. The nine elements framework has been used in several research papers (Elsafty, Elsayed, \& Shaaban, 2020; Elsafty \& AlNawaly, 2020; Elsafty \& Ragheb, 2020; Elsafty \& Abadir \& Sharawy, 2020; Elsafty, A., Elbouseery, I., \& Shaarawy, A., 2020).

Accordingly, the paper used the Nine Elements Framework/Model (ElSafty, 2018) to properly analyze and identify the problem of this paper in more details by applying and discussing each element of this model, which focuses on

Entering the depth of organizations and analyzing the external and internal environment, and through this we were able to identify the mutual impact between Turkish Islamic banks and the internal and external environment for them as follows:

\section{Organization}

There are five Turkish Participatory banks (Ziraat Katılım Bankası A.Ş , Vakıf Katılım Bankası A.Ş, Albaraka Türk Participation Bank Inc, Kuwait Turk Participation Bank Inc, Turkey Finance Participation Bank Inc) there are variance between private and governmental banks but all of them controlled by turkish central Bank according to Banking Law No. 5411 of October 19, 2005 (MÜCAHIT ÖZDEMIR, 2018).

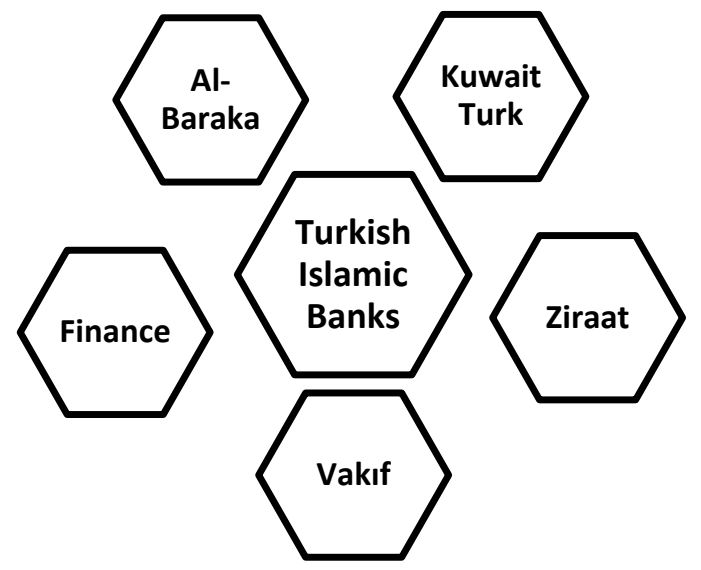

Figure 1.2 Five Turkish Islamic Banks 


\section{Management functions}

Our research aims to measure the impact of CSR activities on performance depending on BSC Tool so we are moving through four major management functions (Planning, Organizing, Direction and control) as we will mention that at next chapter literature review about BSC Tool.

\section{Business Function}

Our research interesting in Turkish participants banks performance according to our problem definition so we have to discuss the Business functions attitude and collect data about business functions in the Turkish Participants banks like (HR, Marketing, Financial, Customer Services, etc.). Competition between Islamic banks with one hand and competition between Islamic and conventional banks on the other hand required enhancing the business functions and products or services that dealing with all stakeholders. There is a supreme body organized for the work of these banks, known as TKBB, The aim of the TKBB is to defend the rights and interests of participation banks within the framework of a free market economy and the principle of full competition in accordance with banking regulations, principles and rules, to work for the healthy growth of the banking system and development of the banking profession, increase competitiveness, ensure necessary decisions that are taken for the creation of a competitive environment and prevent unfair competition and implement and demand the implementation (TKBB, 2018).

\section{Organizational level}

Through discussion with HR manager in Kuwait Turk Bank we explore that the CSR Plans and execution activities take high priority in all management levels from the top of organizational structure to lowest level, This is due to several considerations, the most important of which is that these activities have become one of the main criteria for the evaluation of the bank.

\section{Geographical}

Our research will cover all Turkish participants' banks branches located in all Turkish states .

\section{Industry}

Our research in financial industry area and constrain in Banking Sector through Islamic Banks Branch as a one of strong arms in Turkish economy which has maintained a continues growth in the last 9 years according to TKBB report 2018 we can notice this very clear from next table.

Table 1.1 number of Turkish participant banks branches (TKBB, 2018)

GDP GROWTH

\begin{tabular}{lrrrr} 
& $\begin{array}{r}\text { GDP } \\
\text { (TL billion) }\end{array}$ & $\begin{array}{r}\text { GDP } \\
\text { (USD billion) }\end{array}$ & $\begin{array}{r}\text { GDP Growth Rate } \\
\text { (\%) }\end{array}$ & $\begin{array}{r}\text { Per Capita Income } \\
\text { (USD) }\end{array}$ \\
\hline 2011 & 1,394 & 832 & 11.1 & 11,205 \\
\hline 2012 & 1,570 & 871 & 4.8 & 11,588 \\
\hline 2013 & 1,810 & 950 & 8.5 & 12,480 \\
\hline 2014 & 2,044 & 935 & 5.2 & 12,112 \\
\hline 2015 & 2,339 & 862 & 6.1 & 11,019 \\
\hline 2016 & 2,609 & 863 & 3.2 & 10,883 \\
\hline 2017 & 3,105 & 851 & 7.4 & 10,597 \\
\hline 2018 & 3,701 & 784 & 2.6 & 9,632 \\
\hline
\end{tabular}

\section{External environment}

Since the AK Party won the Turkish elections in 2002 until now, the Islamic banking sector in the country has witnessed a great development, through the government providing the necessary support, issuing laws supporting this sector and opening investment opportunities for foreigners, especially from the Arab region.

\section{Economic factors:}

According to World Bank website (World_Bank, 2020)) the data bank show that many good indicators about Turkish economy Global growth decelerated to an estimated 2.4 percent in 2019 , the slowest pace since the global financial crisis, and is expected to gradually rise to 2.7 percent by 2022 . 
Table 1.2 turkey country profile (World_Bank, 2020)

\begin{tabular}{lllll}
\hline Country Profile & 1990 & 2000 & 2010 & 2018 \\
\hline GDP (current US\$) (billions) & 150.68 & 272.98 & 771.9 & 771.35 \\
GDP growth (annual \%) & 9.3 & 6.6 & 8.5 & 2.8 \\
Inflation, GDP deflator (annual \%) & 58.2 & 49.3 & 7 & 16.4 \\
Agriculture, forestry, and fishing, value added (\% of GDP) & 17 & 10 & 9 & 6 \\
& & & & \\
Industry (including construction), value added (\% of GDP) & 31 & 27 & 25 & 29 \\
& & & & 30 \\
Exports of goods and services (\% of GDP) & 13 & 19 & 20 & 31 \\
Imports of goods and services (\% of GDP) & 18 & 23 & 25 & 30 \\
Gross capital formation (\% of GDP) & 25 & 24 & 27 & 30.7 \\
Revenue, excluding grants (\% of GDP) & 13.7 & 17.2 & 31.7 & -2.2 \\
Net lending (+) / net borrowing (-) (\% of GDP) & -3 & -5.7 & -3 & \\
\end{tabular}

\section{$\underline{\text { Social factors }}$}

With the economic revolution that occurred in Turkey, a new segment of value-oriented businessmen appeared, which helped the growth of the Islamic banking sector in the country.

More than $98 \%$ from Turkish people are Muslims so they prefer dealing with Islamic banking sector.

So the Islamic banking sector is matching with people culture especially after growth in people income according next figure.

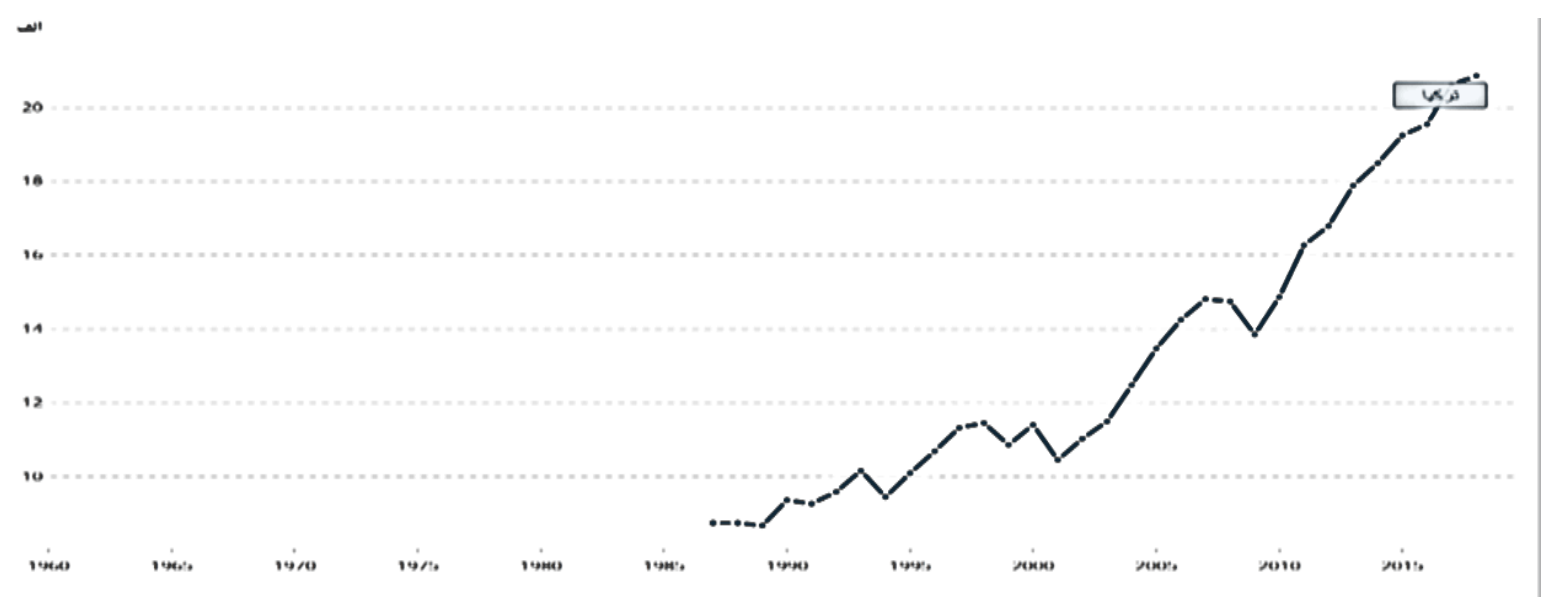

Figure 1.3 Per capita gross national income (World_Bank, 2020)

\section{Technological factors}

All participant banks develop many procedures by internet and mobile phones so that our research take the BSC to measure performance through main four elements one of this elements is processes development now the technology involved in all banking processes and all employers deal with technology from the smallest employee to the chairman.

All around the world banking is going through a rapid transformation from conventional channels to digital channels. Those banks which cannot keep up with this transformation will

Face problems. In order to keep up with transformation it is necessary to read the dynamics and global trends accurately and revise corporate strategy accordingly. At Albaraka Turk, with the vision of being the best participation bank in the world, we strive to make innovation and digitalization our corporate culture (TKBB, 2018). 


\section{Environmental Factors}

The Turkish winter is considered very harsh compared to other regions in the world, where temperatures sometimes reach -10 degrees, which requires many actions to mitigate the effects of this weather, especially in the camps for the displaced on the Syrian border, and there are many projects carried out by Turkish institutions in this regard, including Islamic banks of course.
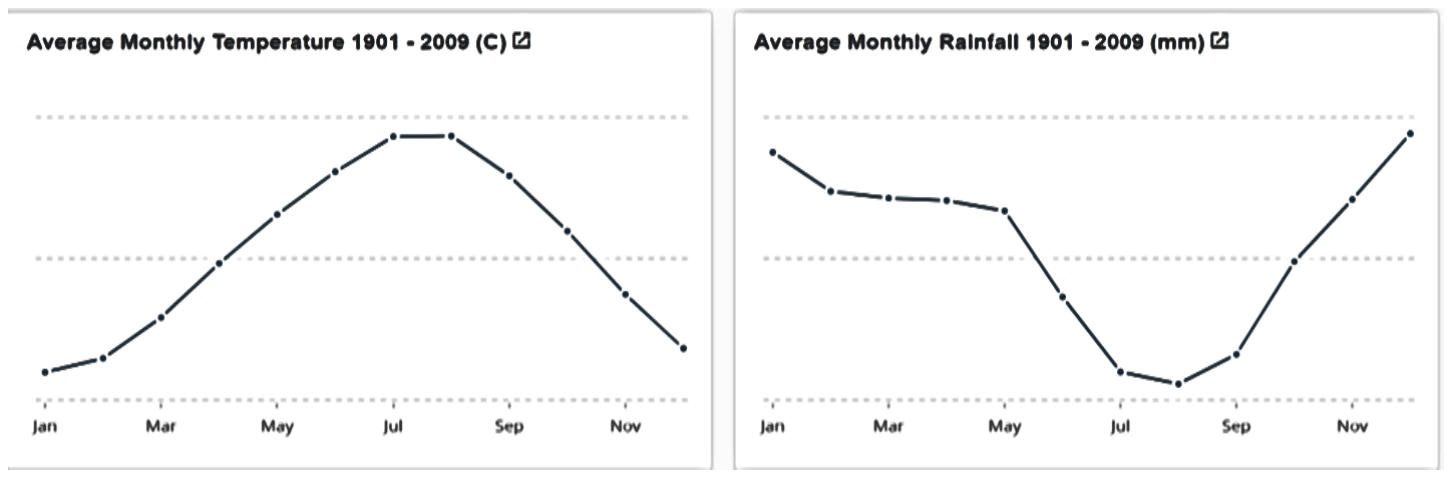

Figure 1.4 Climate Change (World_Bank, 2020)

\section{Legalization factors}

All Turkish Islamic banks are subject to central bank supervision in accordance with the banking laws in Turkey. It is not permissible to designate these banks in Islamic banks according to the constitution of the Turkish state and they are called participations banks.

\section{Internal environment}

Our research will deal with all internal environment components like (employers, customers, management and other stakeholders) this is through the measuring tool BSC used to measure the performance of the organization.

\section{Stakeholders' analysis}

Through our meeting with Mr. Murad Hakan (the executive manager) at one of Al-Baraka Bank at Istanbul city he talked about bank stakeholders as the backbone of the bank, all bank activities around stakeholders' satisfaction, so we have to do our best to satisfy stakeholders. He mentioned many kinds of stakeholders as shown at next figure 1.5:

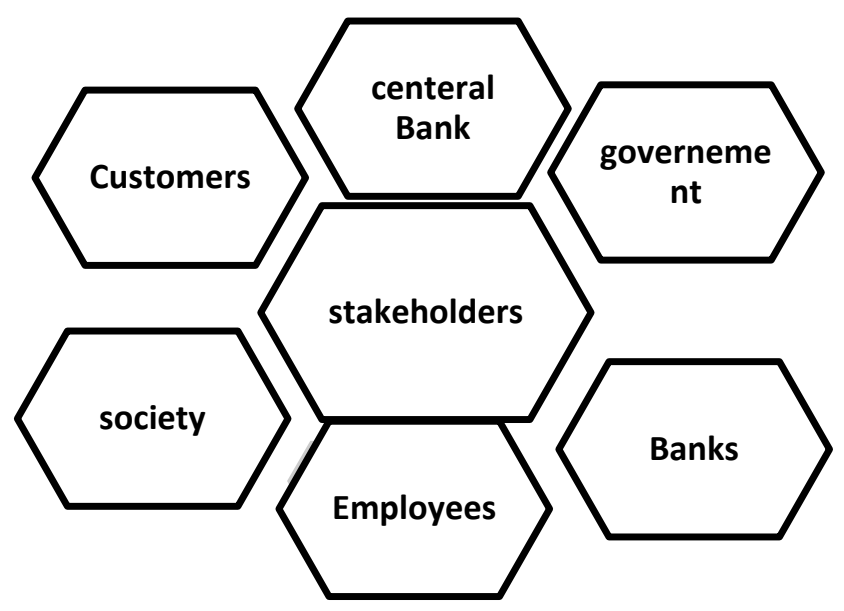

Figure 1.5 Bank Stakeholders

According to Mr. Murad they bank management try to get stakeholders satisfaction through many channels and the strongest channel is CSR Activities.

\section{Literature Review}

\section{What is corporate social responsibility?}

"there is one and only one social responsibility of business - to use its resources and engage in activities designed to increase its profits so long as it stays within the rules of the game, which is to say, engages in open and free competition 
without deception or fraud" (Friedman, 1970). When Friedman (1970) says this statement he Did not imagine that he opened the door wide to establish a new field in the science of management called CSR did Also he did not imagine that a new school was founded to break his idea and towards the support of the idea of CSR and even make it one of the pillars of the companies and success.

So far, there is no universal definition for CSR because the CSR related all corporation fieldes and many of management pioneers defined CSR form diferent ways, but it generally refers to Clear business practices that depend on ethical values, compliance with legal requirements, and respect for people, communities, and the environment. So we can know the defination of CSR from tow sides as follows:

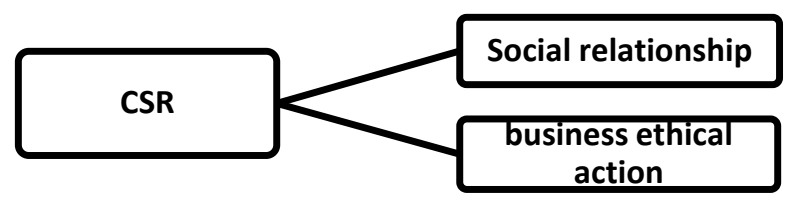

Figure 1.6 CSR Definitions (Friedman, 1970)

\section{CSR as a social relationship}

According to Bummer (1991) in his book, tried to define CSR as some of company actions towards the society; he summarized these actions in three action types the first type Actions performed that go beyond the corporation's domain of authority or permissibility, Actions Non-performance of acts within the corporation's domain of responsibility and Inferior performance of acts within the latter domain.

We can notice the social wise also at the definition "business encompasses the economic, legal, ethical and discretionary expectations that society has of organization at a given point in time", Carroll (1999) consider CSR the corporate voice at society (Caroll a. B., 1999).

Over time, the institutional view of social responsibility has evolved, and definitions have varied. Some writers have become convinced that CSR is one of the reasons for the welfare of societies. We can notice when we read this "in the modern commercial area, companies and their managers are subjected to well publicized pressure to play an increasingly active role in [the welfare of] society." (Balabanis G, 1998).

When we consider CSR as a relationship between company and society, superficially stated, CSR, as a definitional concept, aims at describing the relationship between business and the larger society surrounding it, and at redefining the role and obligations of private business within that society, if deemed necessary (Keinert, 2008). According to these definitions, we can consider the CSR as the social voice inside the company. It means how the corporate can perform its business with positive impact on the society. The company doesn't live alone and it has responsibilities towards its society.

\section{CSR as a Business ethical action}

When we look at the CSR from the ethical wise, we most frequently encounter this definition; The ethical behavior of companies towards society; management acting responsibly in its relationships with other stakeholders, who have a legitimate interest in the business. "CSR is the continual commitment by business to behave ethically and contribute to economic development, while improving the quality of life of the workforce and their families as well as of the local community and society at large" (Moir, 2001). The relationship between CSR and Business ethics is Avery strong relationship so that we have to know more details about business ethics and its tools.

\section{Global business and CSR:}

The engagement of business firms in social responsibility is considered similar to an investment in any other product attributes such as quality, service, or reputation that contribute to the profit-making of the firm (Williams, 2000). This is the new trend of the business firms, which play the game with its rules, know that it is a very important approach to build its good reputation by contributing to the socity with CSR activities. As we have seen, in a globalized world, the capacity of the state - to regulate economic behavior and to set the conditions for market exchange- is in decline, so that some companies contribute to state services and governments to build good reputation in the society.

\section{What is organizational performance?}

Organizational performance is the ultimate dependent variable of interest for researchers concerned with just about any area of management. Market competition for customers, inputs, and capital make organizational performance essential to the survival and success of the modern business. 
As a consequence, this construct has acquired a central role as the deemed goal of modern industrial activity. Marketing, operations, human resources (HR), and strategy are all ultimately judged by their contribution to organizational performance (Pierre J. Richard, 2009). ORGANIZATIONAL PERFORMANCE comprises the actual output or results of an organization as measured against its intended outputs (or goals and objectives). Specialists in many fields are concerned with organizational performance including strategic planners, operations, finance, legal, and organizational development (wikipedia, 2018).

Factors that impact on organizational performance

"one of the most comprehensive frameworks for Organizational Performance Assessment (OPA) is the Institutional and Organizational Assessment Model (IOA Model) elaborated by Universally and the International Development Resource Center (IDRC). This model views the performance of an organization as a multidimensional idea, that is, as the balance between the effectiveness, relevance, efficiency, and financial viability of the organization (see schematic diagram below). The framework also posits that organizational performance should be examined in relation to the organization's motivation, capacity and external environment, indeed.

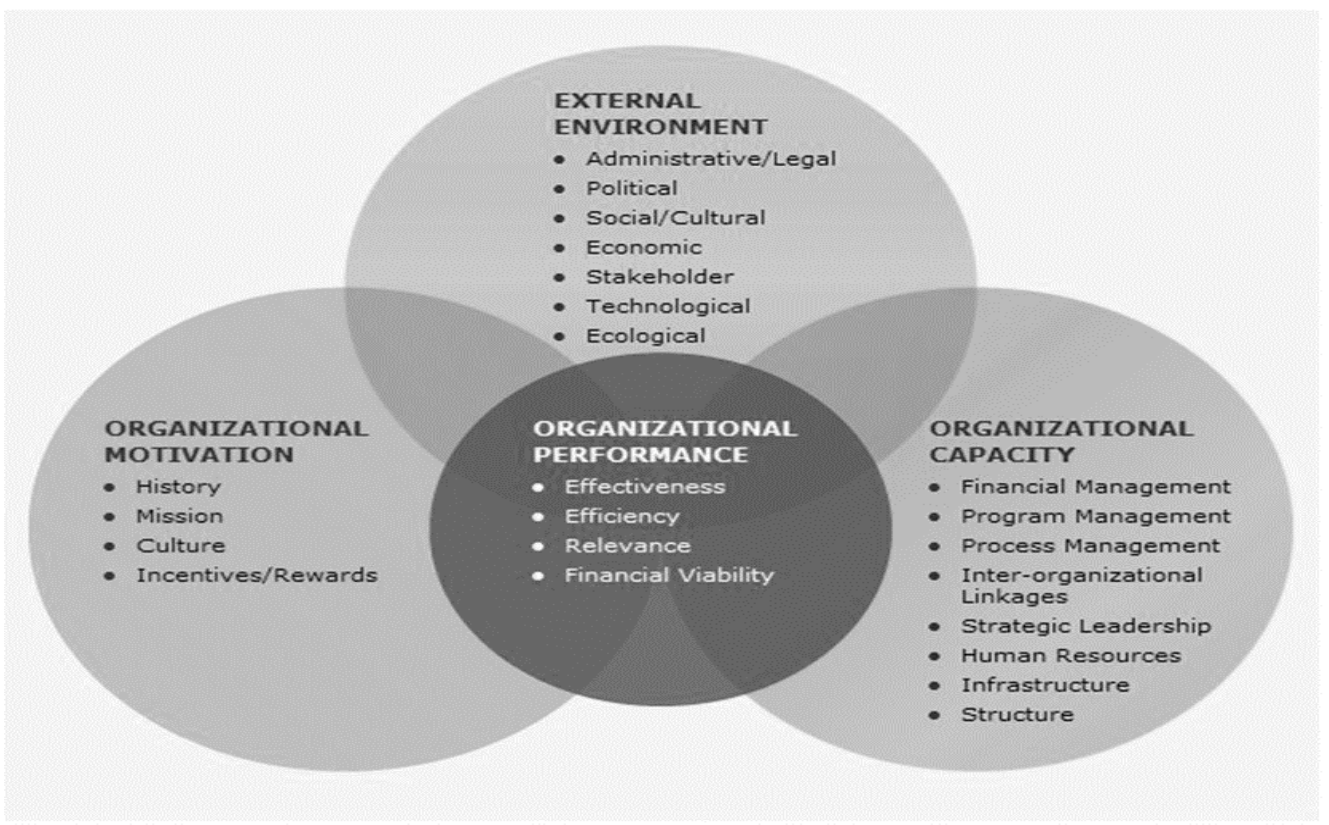

Figure 1.7 Institutional and Organizational Assessment Model (IOA Model) (Rojas, 2019)

\section{Some tools that we can use to get performance measurement:}

1. Cost of quality: measured as budgeted versus actual.

2. Variances: measured as standard absorbed cost versus actual expenses.

3. Period expenses: measured as budgeted versus actual expenses.

4. Safety: measured on some common scale such as number of hours without an accident.

5. Profit contribution: measured in dollars or some common scale.

6. Inventory turnover: measured as actual versus budgeted turnover (Inman, 2018).

\section{Balanced Scorecard as a tool for measuring performance}

The balanced scorecard is a performance measurement tool developed in 1992 by Harvard Business School professor Robert S. Kaplan and management consultant David P. Norton. Kaplan and Norton's research led them to believe that traditional financial measures, like return on investment, could not provide an accurate picture of a company's performance in the innovative business environment of the 1990s. Rather than forcing managers to choose between "hard" financial measures and "soft" operational measures — such as customer retention, product development cycle times, or employee satisfaction - they developed a method that would allow managers to consider both types of measures in a balanced way (Hillstrom, 2019). 


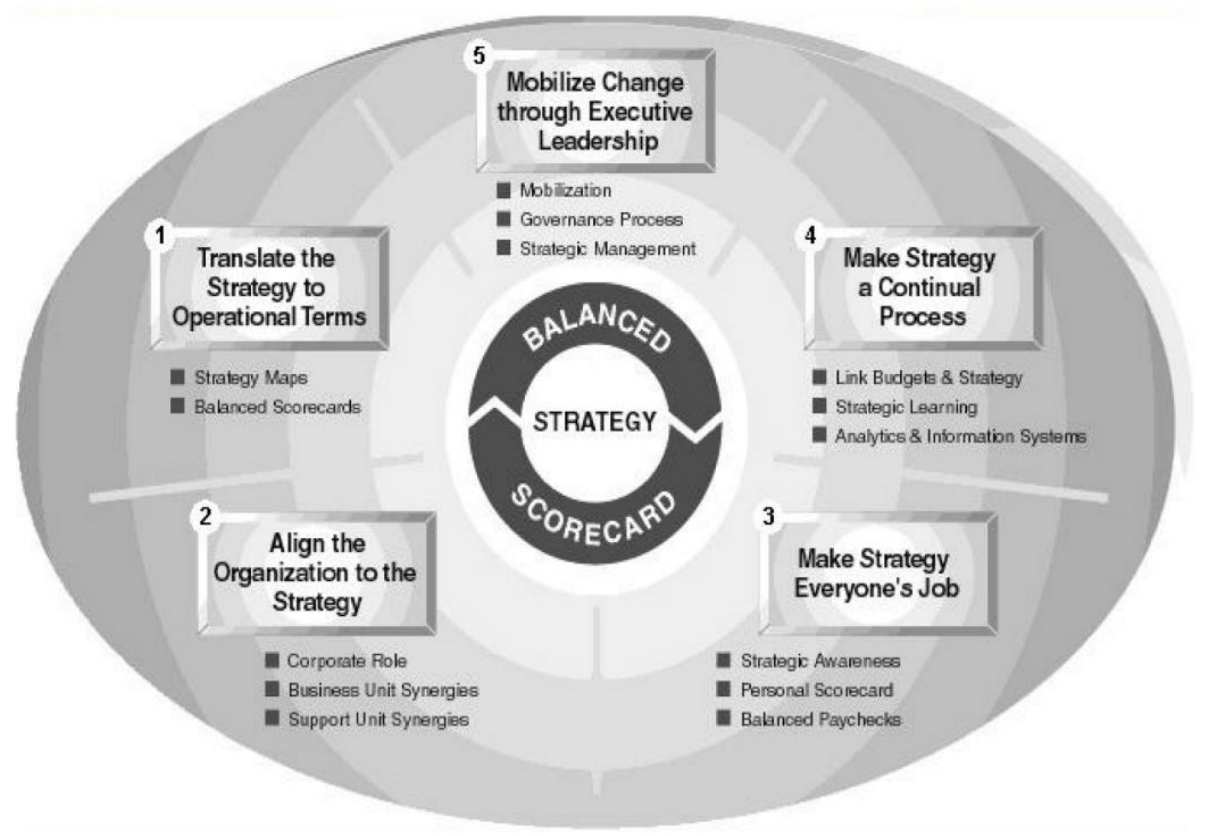

Figure 1.8 The principles of strategy focused organization (Norton, 2001)

According to an article which published at 2004 in Harvard business school review the founders of BSC (Kaplan \& Norton) Explained the definition of BSC " it is a tool that helps to translate the mission of the organization and its strategy to the goals and measurements and provide a set of ideas and principles to measure the performance of the organization, which helps in the tasks performance and communication between strategy, mission and tasks also it coordination between individual work and organizational work" (Norton, 2004) It is an evaluation tool, as well as a strategic tool (Horngren, 2005).

In 2011, (Kaplan \& Norton) were able to develop the business model to extend from a simple department to follow up on strategic plans to follow up on executive plans and achieve short-term goals as well. This development was one of the most important features that distinguished this model (Norton, 2001).

\section{Models and Theories of CSR}

\section{CSR Pyramid}

According to (Caroll a. B., 1999), CSR "involves the conduct of a business so that it is economically profitable, law abiding, ethical and socially supportive. To be socially responsible then means that profitability and obedience to the law are foremost conditions when discussing the firm's ethics and the extent to which it supports the society in which it exists with contributions of money, time and talent". Carroll's concept of CSR consists of four dimensions as presented in Figure (1.9), that the CSR consists of four factors showing them as ordered layers which he labeled economic, legal, ethical and discretionary responsibilities (Visser, 2006).

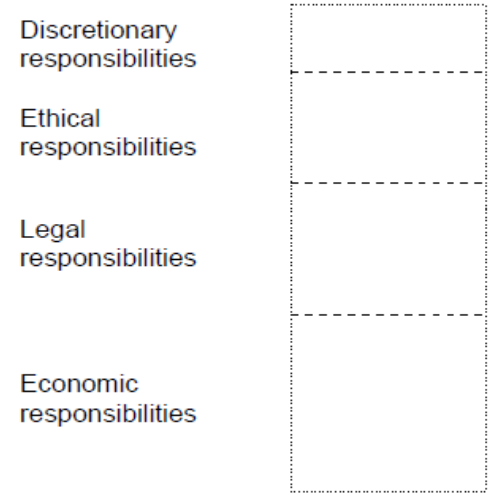

Figure 1.9 Social Responsibility Categories (Carroll, 1979) 
A model which later on was revised to be in the form of pyramid by Carroll (1991) was demonstrated by (Jamali, 2007) in their own work, as presented in Figure (2.9) explaining the pyramid of the CSR function and sorting the "Total Responsibility" to four levels:

1. "Economic Responsibility": organizations should be productive and profitable and meet the needs of consumers.

2. "Legal Responsibility": organizations are obliged to work within existing legal frameworks.

3. "Ethical Responsibility": organizations must follow socially established moral standards.

4. "Discretionary Responsibility": organization's voluntary corporate activities must attempt to help other people and contribute to the well-being of society. (Garcia-De los Salmones, 2005).

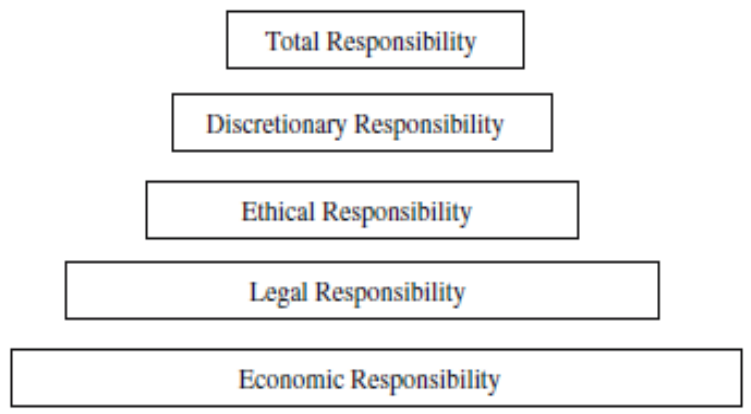

Figure 1.10 Hierarchy of Corporate Social Responsibilities (Carroll, 1991)

\section{John Elkington Triple Bottom Line (1994-1998)}

There are tools that have been developed to measure CSR like the triple bottom line (TBL), which was established in the 1990's through the work of Elkington. "TBL is "an accounting system that considers more than the traditional financial "bottom line". As well as financial outcomes, a company (or Government's) performance should be measured against its social and environmental responsibilities; meaning that the managers should think in terms of "social bottom line", "environmental bottom line" as well as "financial bottom line". Companies exist on Wealth creation and to achieve that they need to develop a long term sustainable bond between social, economic and environmental factors." (Elkington, 1994) In his book "Triple Bottom Line" (1994) he defined the seven drivers of Triple bottom line as shown in the following diagram

$$
\text { Old Paradigm } \quad \rightarrow \quad \text { New Paradigm }
$$

1 Markets

2 Values

3 Transparency

4 Life-cycle technology

5 Partnerships

6 Time

7 Corporate governance

Source Wealth, 1994
Compliance

Hard

Closed

Product

Subversion

Exclusive

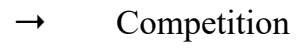

$\rightarrow \quad$ Soft

$\rightarrow \quad$ Open

Function

$\rightarrow \quad$ Symbiosis

Inclusive

\section{Burlingame and Young's Four Models}

A model consisting of four parts was presented by Burlingame and Young in 1996. They described CSR as a whole by articulating corporate philanthropy. These models are namely; Ethical/Altruistic Model, Neoclassical/ Corporate Productivity Model, Political Model and Stakeholders Model (Burlingame, 1996).

\section{Ethical/ Altruistic Model}

This model pays respect to the relationship between the corporation and its community. It can also be described as the citizenship approach which does not separate the corporation from the community it exists within. This scenario applies for those corporations that are created, motivated and sustained by their philanthropic outlook. Not many corporations can fit this model to all their CSR activities, but many direct a lot of activities towards this direction." While man family owned firms might have commercial dimensions to their CSR strategies. They often take an ethical and often religious 
approach to their CSR philosophy" (Logan, 1997).

\section{Neoclassical/ Corporate Productivity Model}

This model approaches CSR as an overall factor to profit increase. This approach can be closely associated with Milton Friedman, the famous 1970's economist. (Friedman, 1970) Argues "that the primary goal of a business is to generate profit to its shareholders and anything that deviates from this primary goal should be avoided." He argued that "corporations should not give into the unchecked and unquestionable demands of CSR".

\section{Political Model}

This model urges the use of" proactive" CSR to trigger governments' involvement and allows the corporations to protect their interest through the public policy sphere. This model most obviously represents the American approach to minimize taxation and legislation and Regulations. This is done by creating or self -regulating innovative and alternative programs.

\section{Stakeholders Model}

This model emphasizes the competing demand of various groups that support the corporation, namely stakeholders. According to Wit and Meyer (2004) Stakeholders theory can be summed up in a few words. It is the balance created by balancing the interest of all stakeholders that creates satisfaction among all stakeholders. This model most clearly can be a representative of the concepts of Triple Bottom Line and Corporate Citizenship (De Wit \& Meyer, 2004).

\section{Stakeholders Approach}

This approach is "mainly concerned with corporations concern with Stakeholders interests, although there seems to be no apparent benefit to them. Stakeholders theory stress on the corporations needs to consider the interests of groups affected by the corporation." (Gibson, 2000). This view comes in contrast with the traditional view of maximization of wealth for owners, i.e. the shareholders. According to (Caroll A. B., 1989), Stakeholders can be divided into primary and secondary. Primary Stakeholders are owners, suppliers, employees, and customers. As for secondary stakeholders, they include environmental groups, society at large, media, local community groups, social interest groups and consumer groups. According to Johnson and Scholes (1999:2013)"Stakeholders are those individuals or groups who depend on the organization to fulfill their goals and upon whom, in turn, the organization depends" (Scholes, 2002) The most commonly motioned stakeholders are employees, customers, stockholders, suppliers, competitors, governments, communities, also bankers and unions as presented by (Fritzsche, 1997) in

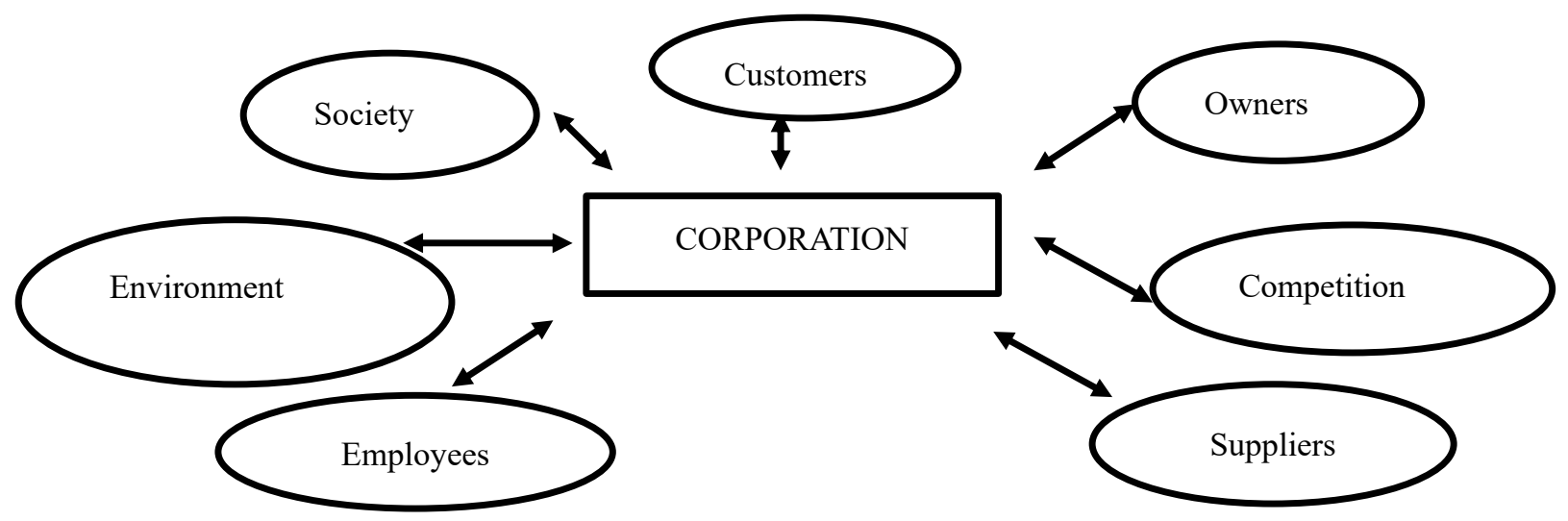

Figure 1.11 Coalitions of Stakeholders (Fritzsche, 1997)

Some theories argue that the judgments of internal and external stakeholders attain the corporations overall sustainability (Collins, 1997). Stakeholders represent the value relationship between the organizations and the stakeholders through "what we are" and "what we represent" (Berman, 1999), hence, stakeholders groups are important for an organization's strategy. Therefore, it is important for each one of the stakeholders groups to establish a strategy with some moral and ethical obligations that correspond with it. "Then some organizations are good at creating a relationship among those stakeholder groups that emphasizes mutual trust and corporations to create competitive advantage amongst the different groups." (Barney, 1994). CSR can be considered a tool that tries to meet most of the Stakeholders' needs and not just some and try doing that based on some ethical basis. The basis includes the main principles such as "employee's fairness and equality, operating ethically and with pride, respect for basic human rights, sustaining the environment for future generations, and to be a caring neighbor in the community within." (Moir, 2001). 


\section{Corporate Social Performance Model}

Corporate Social Performance (CSP) is "the degree to which the firm makes use of socially responsive processes, the existence and nature of policies and programs designed to manage the firm's societal relationships, and the social impacts (i.e. observable outcomes) of the firm's actions, programs and policies". (Beeston, 2008). Corporate Social Performance describes process and outcomes that endorse CSR. This definition of CSP by (Wood, 1991) focuses on principles, processes and outcomes of a business; a business organization's establishment of principles of social responsibility, processes of social feedback, and policies, programs, and tangible outcomes as they relate to the firm's relationships with society. Wood (1991) displayed a model modified "based on some advancements to (Wartick, 1985) Corporate Social Performance (CSP) model through emphasizing on both, the processes as well as the outcomes" (Meehan, 2006). Wood's model of CSP is shown in Figure 2.12

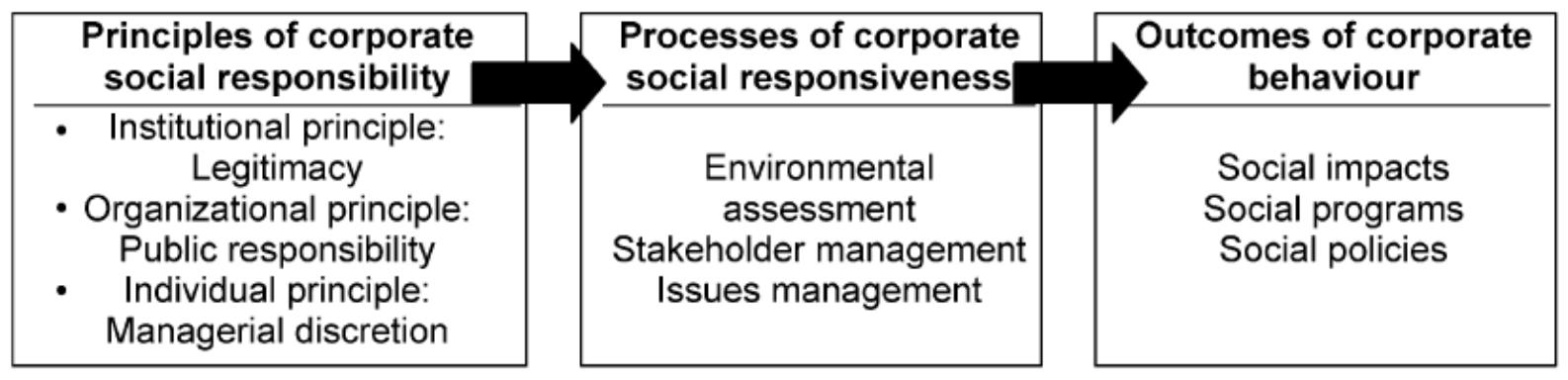

Figure 1.12 Wood's Social Performance Model (Wood, 1991)

\section{Methodology and data collection}

This paper will confirm stakeholders approach and will depend on stakeholder model which shown previously in Fritzche model (Fritzsche, 1997) and follow the narrative approach, which mean making interviews with stakeholders segments and discuss with them about our problem through question and get answers face to face, we determined stakeholders segment which has a direct relationship with Turkish Islamic banks as shown in next figure:

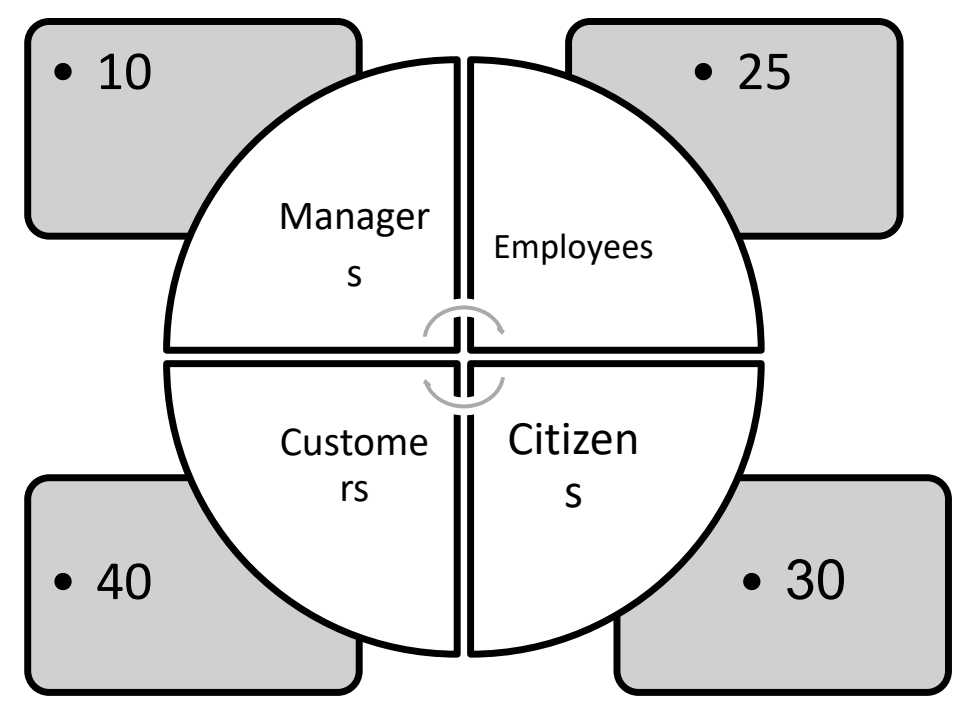

Figure 1.13 stakeholders segment

According to our tool for measuring organizational performance (BSC) we posed two different questions for each segment, according to their nature and ability to answer, and these answers were discussed in depth with the stakeholders.using the methodology of Narrative.

\section{Managers discussion questions}

Q1: Do you think that CSR Activities gave your Bank a good competitive position?

Q2: In your opinion, what are the CSR activities that could positively affect the bank's high performance?

\section{Employees questions}

Is your bank has specialists employee in CSR projects?

Have some operations in the bank been developed to suit CSR projects? 


\section{Customers questions}

Do you consider that the bank's social activities projects were a reason for dealing with it?

Did society benefit from the presence of Islamic banks?

\section{Citizens questions}

Did society benefit from the presence of Islamic banks?

Do you encourage more Islamic banks in Turkish society?

We have at this paper 8 questions covering four performance sides of BSC (Financial, Customers, Process, R\&D) and related them with CSR activities.

After we collected data from stakeholder we analyzed data and test our conceptual framework which shown next figure:

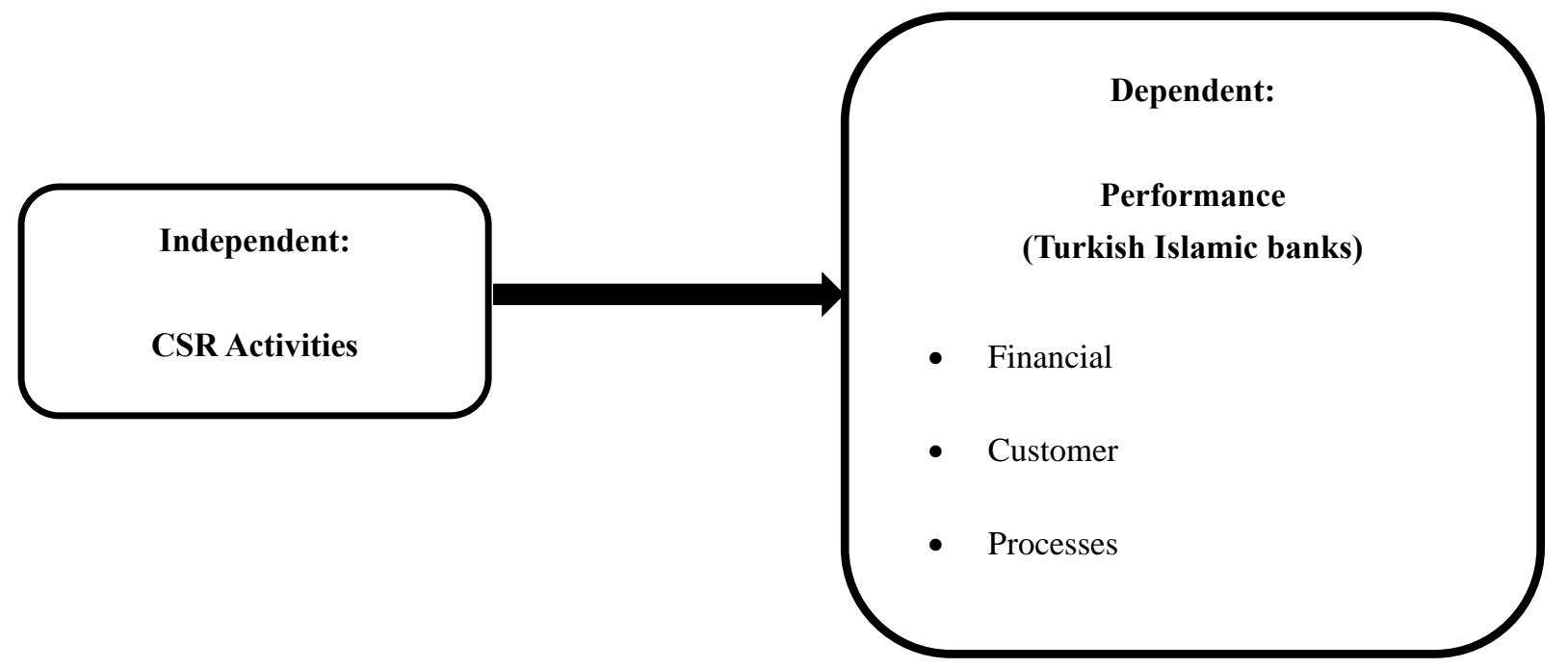

Figure 1.14 The research theoretical framework

We can notice the relationship between major independent variable (CSR activities) and dependent variables through question as shown next table.

Table 1.3 relationship between Questions \& Variables

Narrative Guiding Discussion Question

Categories

Stakeholder

1. Do you think that CSR Activities gave your Bank a good competitivı Financial performance position?

(Competitive position, Ris] Managers

2. In your opinion, what are the CSR activities that could positivel: Rate, Profit, Interest rate,) affect the bank's high rates?

3. Is your bank has specialists employee in CSR projects?

$\mathrm{R} \& \mathrm{D}$

Employees

4. Have some operations in the bank been developed to

Processes

Employees suit CSR projects?

5. Are the procedures for participating in the bank's social activitie:

Customers available and easy for you?

6. Did society benefit from the presence of Islamic banks?

Customers

Citizens

7. Do you encourage more Islamic banks in Turkish society? 


\section{Narrative Discussion and analysis:}

\section{Financials as indicator of Performance:}

- Islamic finance is a very emotional approach, which make it social acceptance and emotional relationship during data collection, using the narrative method. As noted by stakeholders discussions about Islamic banks, in an emotional way rather than rational.

- Stakeholders have a good impression and feel that they are performing an Islamic religious duty, and this was clear among the elderly and Arab nationalities in Turkey more than other segments.

- The advertising campaigns launched by these banks have contributed to increasing this feeling, as they contain many meanings of religious orientate, all of which were clearly indicated by stakeholders within words/sentences during collecting data:

- I feel satisfaction when I deal with Islamic banks

- I hope seeing more and more Islamic banks for our Islamic culture and sharia

- I do not agree to deal with other banks which make anti sharia transactions

- I do not accept dealing with interests through traditional banks

- Some people say all banks are similar but I take Islamic fatwa so I am dealing with Islamic banks

- I heard our president say zero interest is the right way in banks so I am dealing with Islamic banks

- When I deal with my Islamic bank I feel comfortable psychologically and Allah satisfaction

- Because of the desire to deal with Islamic banks, we received large capital from the Arab Gulf region during the past few years, and our profits increased, of course.

2. Some of CSR activities affecting more than others and make direct and speed reputation like educational scholarships, Employment fairs, e.g. when some banks launched direct social projects affecting the lives of customers and citizens, this had a strong effect on improving the bank's reputation and increasing customer demand for it. An example of this is what a bank has done to offer university scholarships to outstanding students, as well as launching a program of installment of university expenses for those who are unable, as well as organizing exhibitions for the appointment of new graduates and searching for job opportunities for them. On the other hand, some banks have launched social responsibility projects in reviving heritage and reprinting some old Turkish books But these projects did not have a strong influence like other projects, although they were considered good and contribute to supporting state projects, but they do not directly affect citizens and customers. We collected many statements refer to this concept like flowing:

- The bank representative visited the university with my son and presented to the students the university expenses installment program as one of the bank's community service projects

- I was able to get a job for my brother through an advertisement for employment in an Islamic bank

- The bank has appointed a number of Arab employees within the refugee support project

- We visited some schools and arranged scholarships for some students who could not afford financially

- We have reprinted some heritage books within the project of reviving the Turkish heritage, but it did not spread much

- We have restored some old mosques as part of the Heritage Revival Project, and we have noted that the community welcomes this

- When we support organizing some sporting events or sports clubs, we find a great deal of community interaction

3. The political conditions open wide field for CSR activities for Turkish organizations the biggest event in this approach is the Syrian crisis.

The Turkish political situation towards some of the crises in the region and receiving refugees from many countries that are going through severe crises such as Syria, Libya and Yemen had a prominent role in pushing official and informal institutions to carry out their social responsibilities Activities as if the state had launched a major competition to compete between institutions to present projects for social responsibility and the Turkish Islamic banks were at the heart of this work, many social responsibility projects have been launched, whether in the form of educational grants or psychological treatment for those affected by wars and other projects. We collected many statements refer to this concept like flowing:

- We have launched some projects to serve refugees, especially Syrians 
- We cooperate with many refugee associations from some countries and arrange some social projects with them, and this helped a lot in improving the reputation of the bank.

- We participate in the Arab Book Fair in Istanbul every year

- I think that we are playing a good role in assisting the country in its direction to contain refugees, and this helps improve the mental image of Turkey in the world.

- I know some Syrian friends who work in Islamic banks

4. Islamic banks take CSR approach as a method for Attracting Arab capital from golf area.

Many Financial institutions from the Gulf countries have contributed to the establishment of some Turkish Islamic banks and there are many shareholders from the Gulf countries in these banks (KWITTURK BANK). The social responsibility projects carried out by Islamic banks have been one of the tools for attracting capital from the Gulf region because of the positive impression of businessmen towards Islamic banks and their agreement. With this approach. We collected many statements refer to this concept like flowing:

- We have the largest percentage of the bank's shareholders with Arab capital, especially the Arab Gulf region

- Many Arab charities invest their money in Islamic banks in Turkey

- We have a good partnership in some social projects with Arab institutions, such as refugee services projects on the Syrian borders

- $\quad$ Endowment laws in Turkey have encouraged many Gulf institutions to establish endowments and participate in social projects, and all of this money is deposited in Islamic banks in Turkey, at most.

5. Some Turkish Islamic banks used banking tools as CSR activities tools like (good loans) some Turkish Islamic banks lunched CSR project involved Islamic banking tools like Good Loans for students and funding small projects for citizens. We collected many statements refer to this concept like flowing:

- We have some banking tools that can be directly classified under social responsibility

- We have benefited from the Murabaha system to finance a car maintenance workshop project for one of my relatives

- Some people benefit from clean, interest-free loans to manage some of their livelihoods and cover their expenses well

- Many citizens have been able to obtain private housing through the mortgage finance system in Islamic banks

- An educational loan is one of the easiest ways to pay for school and university expenses and does not need large requirements. Even foreigners benefit from it.

6. Some of CSR activities made a boom in some banks, such as participating in the production of mass dramas (vakifbank) When the bank participated in the production of one of the historical series that talked about the founding of the Ottoman Empire and the number of views exceeded one billion views around the world, it was like a rediscovery of the bank and the prosperity of its reputation inside and outside Turkey and the bank presented itself as one of the sponsors of this historical series, which helped a lot in marketing it. We collected many statements refer to this concept like flowing:

- The association of the bank's name with the Artugruel series was one of the reasons for the very large spread in Turkish society and outside Turkey as well

- The bank's participation in the production of some television programs in Ramadan was very good for its spread and good reputation, not the community

7. The most CSR Activities make competitive advantage these are related supporting and developing Islamic historical archeology. Zaraaat Bank lunched some social projects in the field of restoring Ottoman heritage, such as Yavuz Sultan Selim Bridge and presented a documentary film about it, and through the promotion of this documentary film, it was able to finance the restoration of the bridge, and that was the reason for the bank to obtain the most desirable bank award in Turkey in general. We collected many statements refer to this concept like flowing: community

- We have participated in the restoration of some old Ottoman mosques, and this makes a good impression on the

- We feel that we are helping the country to grow tourism. When we are interested in some heritage revival projects, that certainly encourages tourism

- We have cooperated with the Ministry of Culture in reviving some ancient Ottoman monuments

- We have participated in the production of some historical artworks on the Ottoman Empire 
8. Many of Turkish Islamic banks Benefited from technology in developing CSR activities like new Apps, social media, big data sciences and advertising through this apps and new technology the customer can find many easy ways to contribute at social projects by dealing with bank mobile applications, also all Turkish Islamic banks using new media and social media approach which contributed a lot to the definition of social banking projects. We collected many statements refer to this concept like flowing:

- I consider that customers using of modern applications has a social dimension in saving their time, effort and money as well

- Often times I donate to some social projects through the bank's application

- Indeed, I got a lot of information about the bank by browsing my social media accounts

- I see through the Internet many ads for good social projects carried out by some banks

- The official websites of Islamic banks are an excellent reference to learn about all the services and projects provided by each bank.

9. Some of CSR activities really influenced bringing some clients to the bank (Campaigns to support Syrian refugees) as we noticed the Islamic finance has very good impression with customers specially Arabic people and old people so when Islamic banks lunched their Social projects for treating some crises, like Syrian crises, This was a major reason for many new clients joining these banks, especially the owners of Arab capital. We collected many statements refer to this concept like flowing:

- I dealt with the bank because it had previously launched a campaign to support Syrian refugees in the camps on the borders

- To one of my relatives, he was appointed in an Islamic bank as a translator. Therefore, he advertises the bank to all relatives and friends.

- I have many Yemeni friends who have become clients of Kuwait Bank, which is left because of its participation in supporting some cultural activities for the Yemeni community in turkey.

- Although the regional crises in some countries seem not good, they were for the bank a good source for customers and increasing transactions, and we are actually racing to attract these customers.

- One of the most important sources for attracting foreign clients is bank's services and the way we deal with them according their conditions.

10. The word of mouse is the most powerful tool between clients for sharing in CSR activities and benefited from them also. During our discussion with them, many clients told us that they joined Islamic banks by talking to their friends and relatives who are involved in these banks. One of the strongest reasons for their conviction in these banks was the talk of friends about the social projects of these banks and how they benefited from them for many customers and individuals, even from non-Turks and foreigners, and among the most famous examples of this were Kuwait Turk Bank clients. We collected many statements refer to this concept like flowing:

- When we came to Turkey seven years ago, my friend told us that the bank he deals with provides good and fast services, so our whole family joined this bank.

- Whenever someone has a problem with any bank, it spreads very quickly through conversations, social media tools, and work groups

- When my bank account was hacked, I informed all of my friends, and some of them moved to another bank

- We did not know much about Islamic banking, and we began to ask our friends and who has a relationship with it until enough information spread, and this made us know its services and its method of work.

11. The growth of Turkish Islamic banks saved many chances for people and society in jobs, loans, micro projects. Many bank employees were proud to talk about their jobs and they are very grateful for their presence in their jobs. Even some Arab employees who joined these banks because of the large number of Arab clients of Islamic banks were very happy with their presence in their jobs and with the spread of the branches of these banks in all Turkish states, I found many good job opportunities And we also talked to some clients about banks financing micro-projects for small investors through good loans. All of these matters ultimately lead to deepening the social dimension of these banks among citizens and customers. We collected many statements refer to this concept like flowing:

- I was a small employee in a traditional bank, and with the beginning of the spread of Islamic banks, I applied to a higher position and it was approved, and I am now at a much higher and better administrative level

- I was working as a manager of a bank in Syria, and after the war, I came to Turkey, learned the Turkish 
language, applied for a job in an Islamic bank, got it, and benefited from speaking Arabic with Turkish

- I have one of my relatives who built a plot of land through Murabahah with an Islamic bank in low installments and without interest, and this is wonderful

- I work as a security guard in an Islamic bank and I am very happy with my work and my dealings with employees and clients, and I have taken many communication skills courses.

- I am studying in a private university and I have benefited from the student loan program to cover study expenses.

12. Some CSR projects reflected directly in society like new gardens, touristic places, public libraries.

One of the mangers told us that in 2016, the vakifbank Bank established a large sports complex and gave it to the state as a kind of support for sports, in addition to the bank owning an ancient sports club that contributed to the achievement of many tournaments in handball, especially women's handball. Another manager told us KuveytTürk bank with the responsibility for "protecting the landmark buildings and historical traces in the city" lunched many projects like "Grand Ortaköy Mecidiye Mosque' a very unique historical building that forms the unprecedented silhouette of Istanbul, the tomb of Buhurizade Mustafa Efendi located in Istanbul, 'AzapkapiSaliha Sultan Fountain' in Istanbul and 'Bursa Kozahan Foundation' in Bursa. We collected many statements refer to this concept like flowing:

- It was really strange for the community for the bank to build a stadium for sports, but this work added to us a lot of customers and a good reputation

- When we established some parks in residential neighborhoods, people used to call the park the name of the bank, and this was a source of happiness for us and a good spread

- Sometimes we participate in paving some roads, and this is a very good thing, and we definitely get state support for these actions

\section{Qualitative Data Analysis}

At this paper qualitative data analysis technique had been taken with MAXQDA Software according to next steps:

1. Collect data from interviews.

2. Make our coding categories (according to BSC).

3. Make coding and sub coding entire categories

4. Make relationship between data and codes.

5. Getting reports from MAXQDA.

We have established four main groups, which are the axes of balanced scorecards, finance, customers, operations, research, and development, in order to be able to measure performance according to social responsibility processes.

Then we created the sub-codes within each group and reached the formation of 14 sub-codes make a relationship between the content and the sub-codes, and at the end we collected the sub-codes within the main groups and extracted the results according to the following reports.

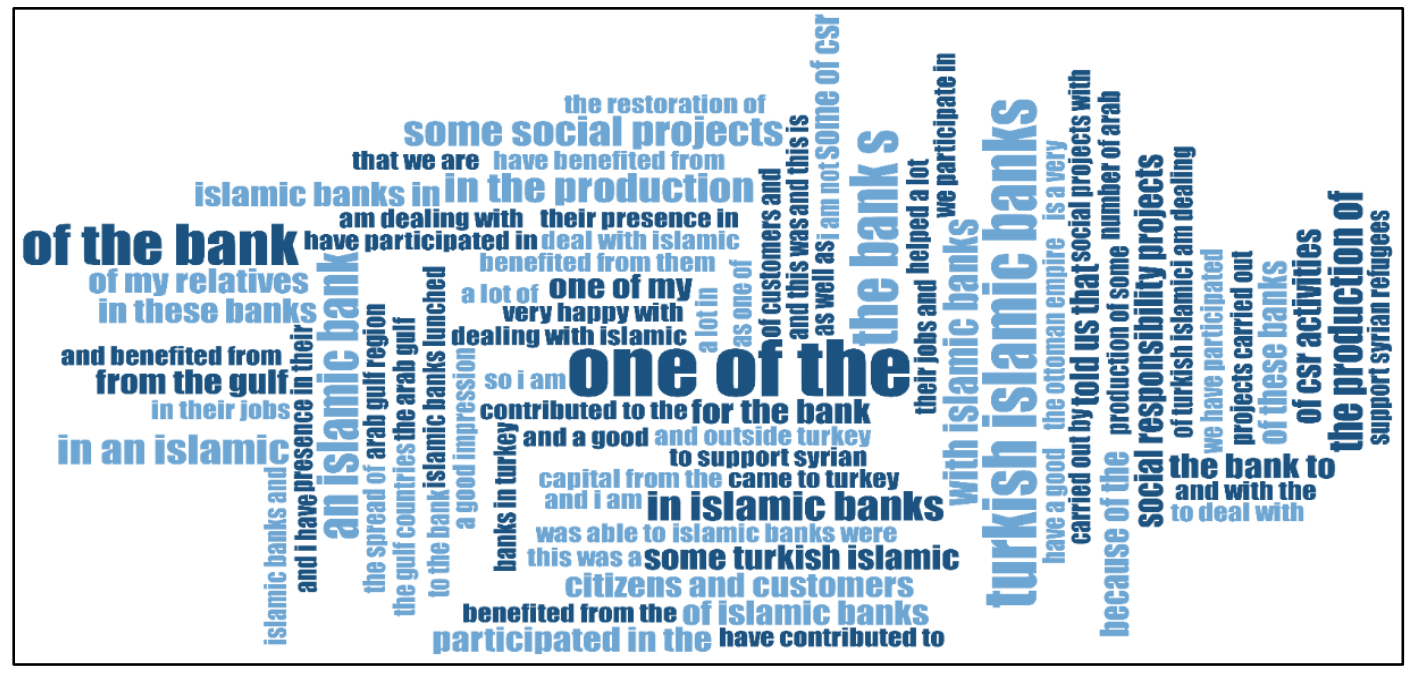

Figure 1.14 Main words analysis 
Table 1.4 sub codes indicators

\begin{tabular}{|c|c|c|c|}
\hline Code & Frequency & Percentage & $\begin{array}{l}\text { Percentage } \\
\text { (valid) }\end{array}$ \\
\hline Customerlcustomers growth & 29 & 15.26 & 15.26 \\
\hline CustomerlCustomer satisfaction & 27 & 14.21 & 14.21 \\
\hline $\mathrm{R} \& \mathrm{D} \backslash$ research & 23 & 12.11 & 12.11 \\
\hline Process $\backslash$ Strong CSR & 21 & 11.05 & 11.05 \\
\hline Customerlgood services & 19 & 10.00 & 10.00 \\
\hline Process $\backslash$ services & 15 & 7.89 & 7.89 \\
\hline Finance/growth & 12 & 6.32 & 6.32 \\
\hline $\mathrm{R} \& \mathrm{D} \backslash$ training & 10 & 5.26 & 5.26 \\
\hline Process $\backslash$ technology & 8 & 4.21 & 4.21 \\
\hline Customerlspeed responses & 7 & 3.68 & 3.68 \\
\hline Processloperations & 6 & 3.16 & 3.16 \\
\hline FinancelCapital & 6 & 3.16 & 3.16 \\
\hline Finance \Profits & 5 & 2.63 & 2.63 \\
\hline weak CSR & 2 & 1.05 & 1.05 \\
\hline R\&D & 0 & 0.00 & 0.00 \\
\hline Process & 0 & 0.00 & 0.00 \\
\hline Customer & 0 & 0.00 & 0.00 \\
\hline Finance & 0 & 0.00 & 0.00 \\
\hline TOTAL (valid) & 190 & 100.00 & 100.00 \\
\hline Missing & 0 & 0.00 & - \\
\hline
\end{tabular}

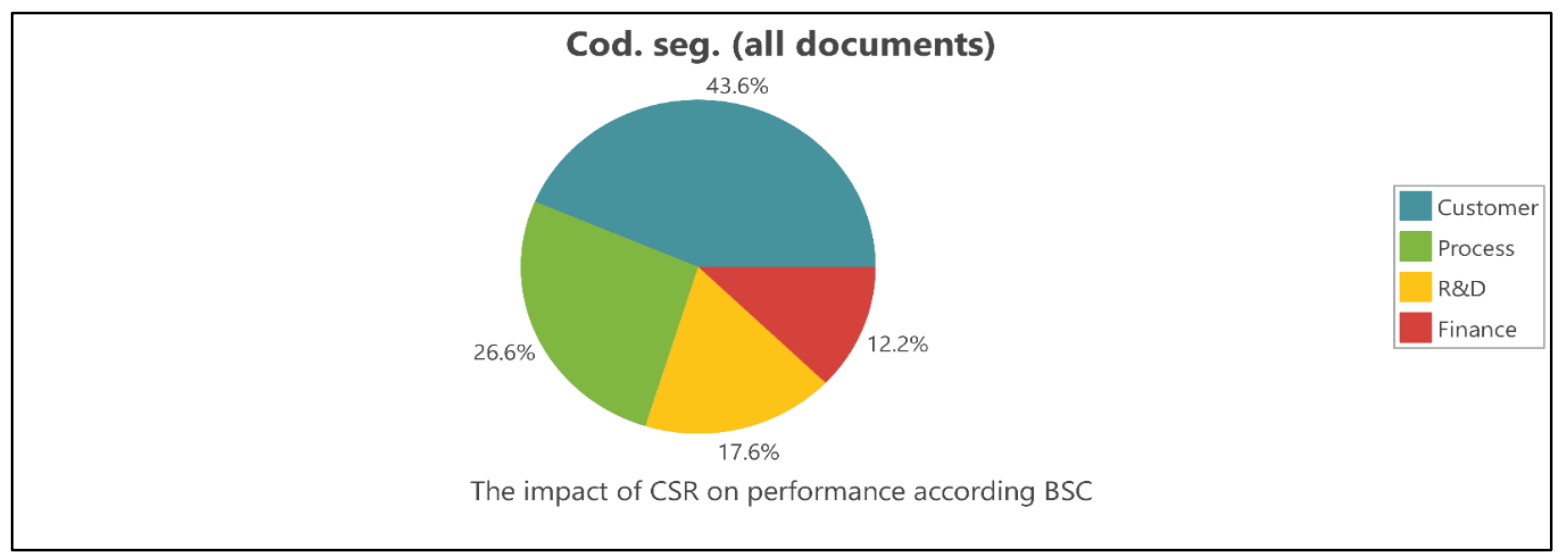

Figure 1.15 Main codes percentages

\section{Conclusion}

Through this figure, it becomes clear to us that the biggest impact on of social responsibility on the growth of Islamic banks in Turkey are those projects that relate to customers and have a clear impact on the stakeholders, as it reached 43.6 out of the total analysis, followed by those projects related to the development of the bank's operations and its method of work. And facilitate its procedures by a percentage 26.2, and projects related to training, research and development come in third place with percentage 17.6 and finally those projects that have affected well in financing and increasing profits. 


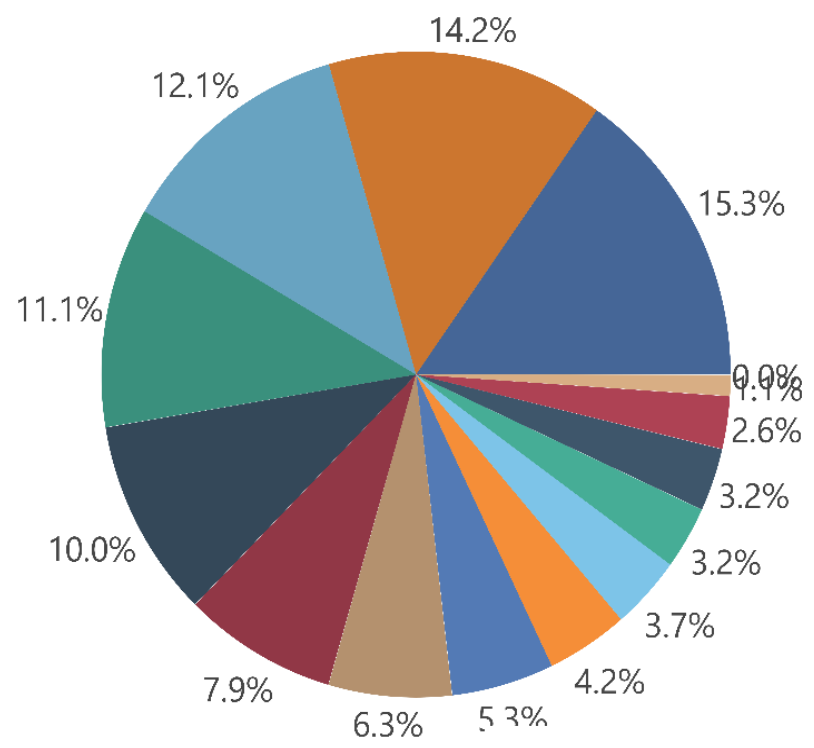

\begin{tabular}{|c|c|}
\hline Customer\customers growth & weak CSR \\
\hline Customer\Customer satisfaction & $R \& D$ \\
\hline$R \& D \backslash$ research & Process \\
\hline Strong CSR & Customer \\
\hline Customer \good services & Finance \\
\hline Process \services & \\
\hline Financelgrowth & \\
\hline$R \& D \backslash$ training & \\
\hline Process $\backslash$ technology & \\
\hline Customer $\backslash$ speed responces & \\
\hline Process\operations & \\
\hline Finance $\backslash$ Cpital & \\
\hline Finance $\backslash$ Profits & \\
\hline
\end{tabular}

Figure 1.16 Sub codes percentages

The paper deployed on a clear path, which is the use of the Balanced Scorecard tool to monitor the performance of the institution and monitor the impact of social responsibility activities on each of the elements of this tool. The independent variable is social responsibility activities, and the dependent variables are financial performance, customers, operations, research and development, as was previously explained.

\section{Emerged Limitations and Obstacles:}

- The research adopted narrative approach and collected data by direct interviews and discussion with stakeholders.

- Data collection method took much long time and more arrangements, but it was sure and accurate.

- Some of our stakeholders were afraid and not collaborated in the beginning and some of them refused any communications and discussions.

- Research covered variety of stakeholders' categories (gender - age - nationality - culture).

- Some of our stakeholders covered as groups specially customers and public people.

- A lot of stakeholders did not differentiate between CSR activities and Waqf activities.

\section{Emerged Themes and Recommendations:}

There is a clear and strong relationship between the institutions planning for their social responsibility projects and the positive impact on their growth, increasing their profits, improving their mental image, and increasing the number of clients. Therefore, strong attention must be paid to this aspect, especially institutions that want to reach a state of global competitiveness. Based on this study, we can recommend some recommendations:

- All organizations need to develop CSR culture between their stakeholders.

- There are activities that directly affect the company's reputation, especially those that directly care for customers and address their problems.

- In the near future, the belief in the field of CSR will become a key element in evaluating organizations.

- The high demand for the idea of Islamic banking may decline with time, but it can be maintained through CSR activities.

- The Turkish Islamic banks need to enter to global competitive area in CSR Field.

- According to our discussion with branches managers we noticed that CSR activities have no special department nor function within the organizational functional chart.

- There are no CSR specialists inside organizational chart and there are no job description for CSR specialist.

- The top management must support the CSR activities of the executive management and work to increase their conviction of the necessity of these activities in improving the performance of banks. 


\section{Further Research Recommendations}

At the end of this paper, we suggest that researchers in the administrative field try to focus on the contribution of corporate social responsibility in developing institutional performance at all levels.

There are many different research surveys that can be added in this area, including the following:

1. Strategic planning for social responsibility.

2. Preparing job cadres and qualifying social responsibility officials.

3. Study the relationship between social responsibility and sustainable development.

4. Social responsibility as one of the tools to confront the Covid19 pandemic.

\section{References}

Balabanis, G. H. C. (1998). corporate social resbonsability and the economic performance in top british companies: are they linked? European Business Review, 25-44. https://doi.org/10.1108/09555349810195529

Barney, J., \&. Hansen, M. H. (1994). Trustworthiness as a source of competitive advantage. Strategic Management Journal, 175-190. https://doi.org/10.1002/smj.4250150912

Beeston, G. K. (2008). A FRAMEWORK OF CORPORATE SOCIAL RESPONSIBILITY FOR ADVERTISING $\begin{array}{lllll}\text { ACCOUNTABILITY. JOURNAL OF MARKETING } & \text { COMMUNICATION, } & \text { 155-169. }\end{array}$ https://doi.org/10.1080/13527260701858539

Berman, S. A. (1999). Does Stakeholder Orientation Matter? The Relationship between Stakeholder Management Models and Firm Financial Performance. The Academy of Management Journal, 488-506. https://doi.org/10.5465/256972

bummer, J. (1991). corporet responsibility and legitimancy. greenwood preess, 20-33.

Burlingame, D. F. (1996). Corporate philanthropy at the crossroads. Indiana University Press.

Caroll, A. B. (1989). Management ethics in the workplace-an investigation. Management Quarterly, 40-45.

Caroll, A. B. (1999). Corporate Social Responsibility: Evolution of a Definitional Construct. Business \& society, 268-295. https://doi.org/10.1177/000765039903800303

Carroll, A. B. (1979). A three-dimensional conceptual model of corporate performance. Academy of management review, 497-505. https://doi.org/10.5465/amr.1979.4498296

Collins, J. C. (1997). Built to last: Successful habits of visionary companies. New York: HarperBusiness.

DE WIT, B., \& MEYER, R. (2004). Strategy: Process, Content, Context. An international perspective. Minneapolis: West Publishing Company.

Elkington, J. (1997). Cannibals With Forks: The Triple Bottom Line of 21st Century Business. London: John Wiley and Sons. https://doi.org/10.1002/tqem.3310080106

Elkington. (1994). Towards the Sustainable Corporation: Win-Win-Win Business Strategies for Sustainable Development. California Management Review, 90-100. https://doi.org/10.2307/41165746

ElSafty, A. (2018). Business Research Methods. Egypt: Lecture Notes, Lecture One.

Elsafty, A. (2018). Lecture 2: Scientific Business Research Problem Definition [PowerPoint slides]. Retrieved from Maastricht School of Management, MBA Degree.

Elsafty, A. (2018). Lecture 2: Scientific Business Research Problem Definition [Lecture]. Retrieved from Maastricht School of Management, MBA Degree.

Elsafty, A. (2020). DrAshrafElsafty Channel. Retrieved from Youtube: https://www.youtube.com/watch?v=y-jDT2iOOhU\&list=PLKSWZdnzp8p3uFLLh2N8_d0W7ZmJDLMjW\&index $=42 \& \mathrm{t}=628 \mathrm{~s}$

Elsafty, A., \& AlNawaly, A. (2020). Role of Co-Working Spaces' Services in Entrepreneurs Growth in Upper Egypt, The Case of Step Co-Working Space. Business and Management Studies, 6(2), June 2020. ISSN: 2374-5916 E-ISSN: 2374-5924. https://doi.org/10.11114/bms.v6i2.4899

Elsafty, A., \& Ragheb, M. (2020). Role of Human Resource Management towards Employees Retention during Covid-19 Pandemic. Business and Management Studies, 6(2), June 2020. ISSN: 2374-5916 E-ISSN: 2374-5924, https://doi.org/10.11114/bms.v6i2.4899 
Elsafty, A., Abadir, D., \& Shaarawy, A. (2020). How Does the Entrepreneurs' Financial, Human, Social and Psychological Capitals Impact Entrepreneur'S Success?. Business and Management Studies, 6(3), 55-71. https://doi.org/10.11114/bms.v6i3.4980

Elsafty, A., Elbouseery, I., \& Shaarawy, A. (2020). Factors Affecting the Behavioral Intention to Use Standalone Electronic Personal Health Record Applications by Adults in Egypt. Business and Management Studies, 6(4), 14-36. https://doi.org/10.11114/bms.v6i4.5066

Elsafty, A., Elsayed, H., \& Shaaban, I. (2020), A Business Analysis Perspective for Engineering Education in Egypt. Journal of Education and Training Studies, 8(5), May 2020. ISSN 2324-805X E-ISSN 2324-8068. https://doi.org/10.11114/jets.v8i5.4721

Elsafty, A., Elsayed, H., \& Shaaban, I. (2020). Educating Engineering Students in Egypt: Recommendations for Improvement. International Journal of Higher Education. https://doi.org/10.5430/ijhe.v9n3p1

Elsafty, A., Elsayed, H., \& Shaaban, I. (2020). Journal of Education and Training Studies, 8(8), August 2020. ISSN 2324-805X E-ISSN 2324-8068. https://doi.org/10.11114/jets.v8i8.4901

Friedman. (1970). The Social Responsibility of Business Is to Increase Its Profits. New York Times Magazine, 122-126.

Fritzsche, D. J. (1997). Business Ethics: A Global and Managerial Perspective. McGraw Hill Companies Inc.

Garcia-De los Salmones, M.-C.-d. (2005). Influence of Corporate Social Responsibility on Loyalty and Valuation of Services. Journal of Business Ethics, 369-385. https://doi.org/10.1007/s10551-005-5841-2

Gibson. (2000). The Moral Basis of Stakeholder Theory. Journal of Business Ethics, 245-257. https://doi.org/10.1023/A:1006110106408

Hillstrom, L. C. (2019). Encyclopedia of Management. Retrieved from https://www.referenceforbusiness.com/ https://www.referenceforbusiness.com/management/A-Bud/Balanced-Scorecard.html

Horngren, C. T. (2005). Introduction To Management Accounting2 13th. New Jersey: Prentice Hall.

Inman, A. (2018). Encyclopedia of Management. Retrieved from https://www.referenceforbusiness.com/ https://www.referenceforbusiness.com/management/Or-Pr/Performance-Measurement.html

Jamali, D. (2007). corporate social responsibility (CSR): theory and practice in developing country context. Journal of business ethics, 243-262. https://doi.org/10.1007/s10551-006-9168-4

Keinert, C. (2008). corporate social Responsibility as iternational strategy. vienna: physica-verlag heidelberg.

Logan, D. E. (1997). Global Corporate Citizenship - Rationale and Strategies. Washington: The Hitatchi Foundation.

Meehan, J. M. (2006). Corporate Social Responsibility: the 3C-SR model. International Journal of Social Economics, 386-398. https://doi.org/10.1108/03068290610660661

Moir, L. (2001). What do we mean by cororate social resposibility? Bedford: MCB Up LTD. https://doi.org/10.1108/EUM0000000005486

Moir, L. (2001). WHAT DO WE MEAN BY CORPORATE SOCIAL RESPONSIBILITY? Corporate Governance, 16-22. https://doi.org/10.1108/EUM0000000005486

MÜCAHIT ÖZDEMIR, H. A. (2018). THE POLITICAL ECONOMY OF THE TRANSFORMATION OF ISLAMIC FINANCE IN TURKEY. istanbul: Seta.

Norton, R. K. (2004). Measuring the Strategic Readiness of Intangible Assets. Harvard Business Review, 113-131.

Norton, R. S. (2001). Transforming the Balanced Scorecard from Performance Measurement to Strategic Management. Accounting Horizons, 147-160. https://doi.org/10.2308/acch.2001.15.2.147

Pierre J., \& Richard, T. M. (2009). Measuring Organizational Performance:Towards Methodological Best Practice. Journal of Management. https://doi.org/10.1177/0149206308330560

Rojas, K. (2019). Types of intervention. Retrieved from https://www.betterevaluation.org/ https://www.betterevaluation.org/en/theme/organisational_performance

Scholes, K. (2002). Exploring corporate strategy. Prentice Hall International.

TKBB. (2018). Participation Banks. Istanbul: Participation Banks Association of Turkey.

Türk_Kuveyt. (2018). Kuveyt Türk Sustainability Report 2018 Going Global with Care Values That Bring us Together. Istanbul: Kuveyt Türk Bank.

Visser, W. (2006). Revisiting Carroll's CSR Pyramid An African Perspective. In M. H. E.R. Pedersen, Corporate 
Citizenship in Developing Countries, 29-56. Copenhagen Business School Press.

Wartick, S. L. (1985). The evolution of the corporate social performance model. Academy of Management Review, 758-769. https://doi.org/10.5465/amr.1985.4279099

wikipedia. (2018). wiki. Retrieved from https://en.wikipedia.org/ https://en.wikipedia.org/wiki/Organizational_performance

Williams. (2000). Corporate Social Responsibility. Academy of Management Review, $117-127$. https://doi.org/10.5465/amr.2001.4011987

Wood, D. (1991). Corporate social performance revisited. The Academy of Management Review, 691-717. https://doi.org/10.5465/amr.1991.4279616

World_Bank. (2020). Data Bank Qountries. Retrieved from data.albankaldawli.org: https://data.albankaldawli.org/country/turkey

\section{Copyrights}

Copyright for this article is retained by the author(s), with first publication rights granted to the journal.

This is an open-access article distributed under the terms and conditions of the Creative Commons Attribution license which permits unrestricted use, distribution, and reproduction in any medium, provided the original work is properly cited. 